\title{
MORPHOLOGICAL AND AGRONOMIC CHARACTERISTICS OF PERENNIAL RYEGRASS (Lolium perenne L.) GENOTYPES
}

\author{
Abdullah OZKOSE ${ }^{* 1}$, Ahmet TAMKOC ${ }^{l}$ \\ ${ }^{1}$ Selcuk University, Faculty of Agriculture, Department of Field Crops, TURKEY \\ Corresponding author: aozkose@selcuk.edu.tr
}

Received: 07.01.2014

\begin{abstract}
Many plants in natural flora including perennial ryegrass loss their genetic variability, suffer from genetic pollution or become extinction. In Turkey, studies on breeding of perennial ryegrass genotype collections are inadequate. This study aimed to determine some plant characteristics of perennial ryegrass plants collected from the natural flora of Ankara. Those genotypes were utilized in order to evaluate for breeding purposes. Seedlings were reproduced in greenhouse after collected seeds from plants were sown in pots. Seedlings were transplanted to the experimental field at $50 \times 50 \mathrm{~cm}$ intervals in Randomized Complete Block Design with four replications during 2005. Data were obtained from the observations and 568 perennial ryegrasses in 2007 and 2008. The observations and measurement of the two year average values ranged from 2.25 to 6.50 (1=very early, $9=$ very late) for the spring re-growth time, 2.75 to 7.75 (1=very light green, $9=$ very dark green) for color, 1.25 to $6.88(1=$ eery low, $9=$ very high) for density, $1.0-8.0$ (1=erect, $9=$ =prostrate) for growth habit, 1.0 - 9.0 ( $1=$ very weak, $9=$ =ery strong) for tendency to inflorescences, 1.0 to $7.5(1=$ very early, $9=$ very late) for time of inflorescence emergence. In the study, furthermore, measurements varied between 19.35 and $48.05 \mathrm{~cm}$ for plant height, 8.31 and $25.54 \mathrm{~cm}$ for length of upper internode, 6.76 and $16.28 \mathrm{~cm}$ for spike length, 6.44 and $14.57 \mathrm{~cm}$ for leaf length, 2.41 and $4.01 \mathrm{~mm}$ for leaf width, 1.68 and $4.87 \mathrm{~cm}^{2}$ for leaf area, 21.23 and 45.52 for leaf shape, 11.63 and 23.75 for spikelet number per spike, 0.031 and $0.151 \mathrm{~g}$ spike $^{-1}$ for seed yield, 1.23 and 2.38 $\mathrm{g}$ for thousand grain weight. The findings showed that there were significant differences among genotypes in terms of investigated traits. The high level of genotypic variability increased the possibility for selection of suitable genotypes. Research results indicated that superior genotypes of perennial ryegrass could be utilized in future breeding programs
\end{abstract}

Key words: Breeding, genetic resources, morphology, natural flora, phenology, variability

\section{INTRODUCTION}

Turfs increase the aesthetic, economic and environmental value of the landscape and provide recreational vegetation, erosion control and other ecological benefits, when established consciously (Kır et al., 2010). Perennial ryegrass (Lolium perenne L.) is one of the most common species for the construction of green areas. Perennial ryegrass is grown for green areas and forage (Acikgoz, 1994; Bolaric et al., 2005). It is native to temperate regions of Eurasia and North Africa (Hoover et al., 1948; Watson and Dallwitz, 1994). It exists also in the natural flora of Turkey (Mill, 1985). Due to foreign pollination, it has high genetic variability (Bolaric et al., 2005).

Natural flora of Turkey has a significant amount of perennial ryegrass (Lolium perenne L.) genotypes and great potential for improvement, however there are few commercialized cultivars. Using genetic resources available, new cultivars can be improved in this way, which also catch an opportunity of sustainable protection of genetic resources and development. It was reported in the study carried out by Surmen et al., (2013) with the aim of determining some forege yield and quality of collected perennial ryegrass plants in the Black Sea Coastal, in order to be on the registered cultivar list for the region will obtain in perennial ryegrass.

Breeding procedure of perennial ryegrass consists of gathering of plants from natural flora, selection of superior species that have characteristics desired, determination of general combination ability, and formation of poly-cross plots that form synthetic variety with general combination ability high-clones, cultivation synthetic seed for some years and determination of quality of grass fields that obtained with synthetic seed.

This study is aimed to determine plant characteristics of 568 perennial ryegrass genotypes, obtaining from natural flora of Ankara and select of superiors in terms of green area and forage.

\section{MATERIALS AND METHODS}

This study is conducted at Konya at 2007 and 2008 as two years. Elevation is $1016 \mathrm{~m}$ above sea level. 
Experiment was located southern part of the Central Anatolia that was a semi-arid continental climate.

During 2007 season, the average monthly temperature is $0.4{ }^{\circ} \mathrm{C}$ in February, the highest temperature is $26.3{ }^{\circ} \mathrm{C}$ in July and August, and average yearly temperature is 13.1 ${ }^{\circ} \mathrm{C}$. During 2008 season, the average monthly temperature is $-3.5{ }^{\circ} \mathrm{C}$ in January, the highest average temperature is $26{ }^{\circ} \mathrm{C}$ in august and the average yearly temperature is 12.3 ${ }^{\circ} \mathrm{C}$. Relative average humidity is $53.8 \%$ in 2007 and 59.4 $\%$ in 2008. Total annual precipitation is $261.7 \mathrm{~mm}$ for 2007 and $293.9 \mathrm{~mm}$ for 2008.

The soil sample is taken from $0-30 \mathrm{~cm}$ depth in trial field. According to the result of the analyses, the soil of the trial field is clay - loamy and alkaline $(\mathrm{pH}=7.7)$, organic matter rate $\left.1.19 \%, \mathrm{EC}(\mu \mathrm{S} \mathrm{cm})^{-1}\right)=193, \mathrm{P}_{2} \mathrm{O}_{5}=$ $10.86 \mathrm{ppm}, \mathrm{K}_{2} \mathrm{O}=221.16 \mathrm{ppm}, \mathrm{Zn}=2.12 \mathrm{ppm}, \mathrm{Fe}=1.30$ ppm, $\mathrm{Cu}=0.82 \mathrm{ppm}, \mathrm{Mn}=4.95 \mathrm{ppm}, \mathrm{Ca}=5800.00 \mathrm{ppm}$ and $\mathrm{Na}=65.49 \mathrm{ppm}$.

Perennial ryegrass genotypes (Lolium perenne L.) collected from natural flora of Ankara were used as a material in the study. The seeds belonging to plants collected from natural flora were planted in pots at greenhouse. The plants were transferred in tubes as soon as they grew noticeably. The perennial ryegrasses in tubes were transferred again in tubes as one for each genotype in four replication when they formed sufficient tiller plants. Seedlings were spaced in $50 \times 50 \mathrm{~cm}$ apart. Those seedlings were planted the date from $20^{\text {th }}$, May of 2005 in Randomized Complete Block Design with four replications. Field was plowed two times in autumn and spring. $150 \mathrm{~kg} \mathrm{ha}^{-1}$ for nitrogen, $150 \mathrm{~kg} \mathrm{ha}^{-1}$ for phosphorus and $150 \mathrm{~kg} \mathrm{ha}^{-1}$ for potassium fertilizer were applied to field before the planting
Plants were managed using the common farming practices such as irrigation, weed control, fertilizing, harvesting and cutting. Plants were watered with drip irrigation. Fertilization was made in the spring in each year after cutting, applied $150 \mathrm{~kg}$ per hectare composite forms $(12 \% \mathrm{~N}, 12 \% \mathrm{P}, 12 \% \mathrm{~K}+20 \%$ organic matter, $0.5 \%$ $\mathrm{Fe}, 0.1 \% \mathrm{Zn}, 0.1 \% \mathrm{Mn})$. Cutting was made with lawn mower after winter at the aim of cleaning, and it was made manually when the seeds ripen in summer. Weeds were controlled by hand hoeing.

In the study, observations and measurements were made at plants in 2007 and 2008 years. Data were evaluated using "Guidelines for The Conduct of Tests for Distinctness, Homogeneity and Stability" UPOV directory for Ryegrass (Lolium spp.) (Anonymous, 1990). Republic of Turkey Ministry of Food Agriculture and Livestock, Variety Registration and Seed Certification Centre's "Guidelines for the Conduct of Tests for Distinctness, Homogeneity and Stability" Document for Grass (ryegrass) (Lolium spp.) (Anonymous, 1998), "National plant Germplasm System" of the plant expression of USDA (Anonymous, 2005) and National Turfgrass Evaluation Program (NTEP) of USA (Morris, 2005). In the spring re-growth time, color, density, growth habit, tendency to inflorescences, time of inflorescences were performed as observation but, plant height, length of upper internode, spike length, leaf length, leaf width, leaf area, leaf shape, number of spikelet per spike, seed yield per spike and 1000 grain weight were evaluated as measurements.

The units of the characteristics and characteristics were described in Table 1. Data which were obtained with the two year average values of the observations and measurement were analyzed using MSTAT-C statistical software package.

Table 1. Morphological characters and descriptions in perennial ryegrass plants

\begin{tabular}{ll}
\hline Characters observed & Description of characters \\
\hline In the spring re-growth time & Scale: $1=$ very early $-9=$ very late \\
Color & Scale: $1=$ Very light green $-9=$ Very dark green \\
Density & Scale: $1=$ very low $-9=$ very high \\
Growth habit & Scale: $1=$ erect $-9=$ prostrate \\
Tendency to inflorescences & Scale: $1=$ absent or very weak $-9=$ very strong \\
Time of inflorescence emergence & Scale: $1=$ very early $-9=$ very late \\
Plant height & The distance between soil surface and portion of the spike $(\mathrm{cm})$ \\
Length of the upper internode & The length of the node of top $(\mathrm{cm})$ \\
Spike length & The distance between spikelet at the bottom and spikelet at the top $(\mathrm{cm})$ \\
Leaf length & Mature leaf length $(\mathrm{cm})$ \\
Leaf width & Mature leaf width $(\mathrm{mm})$ \\
Leaf area & Leaf width $\mathrm{x}$ leaf length $\left(\mathrm{cm}{ }^{2}\right)$ \\
Leaf shape & As a ratio, leaf length / leaf width \\
The number of spikelets per spike & Number of spikelets per spike $(\mathrm{spikelet} \mathrm{/} \mathrm{spike)}$ \\
Seed yield per spike & Seed yield per spike $(\mathrm{g} / \mathrm{spike})$ \\
Thousand grain weight & Thousand grain weight \\
\hline
\end{tabular}




\section{RESULTS AND DISCUSSION}

In terms of re-growth

Research results showed lowest for 2.25 (early) and the highest for 6.50 in terms of re-growth in the spring time and 0.780 for standard deviation. Genotypes were found $26.58 \%$ for early, $71.30 \%$ for medium and $2.11 \%$ for late (Table 2). Perennial ryegrasses should be early regrowth. In this way, a longer time green area and grazing period was achieved. Re-growth in the spring was closely related to the climate. The duration of the winter season, the severity of the cold, the snow cover, the number of days below zero etc. has a direct impact on growth again in the spring time. Diversity genetic of perennial ryegrass was important as much as climate. The 568 genotypes of perennial grass showed great difference in terms of regrowth in the spring time.

Table 2. Statistical parameters and frequency distribution of in the spring re-growth time, color, density, growth habit, tendency to inflorescences, time of inflorescence emergence, plant height, length of the upper internode in 568 perennial ryegrass genotypes

\begin{tabular}{|c|c|c|c|c|c|c|c|c|c|c|c|}
\hline \multicolumn{3}{|c|}{ In the spring re-growth time } & \multicolumn{3}{|l|}{ Color } & \multicolumn{3}{|l|}{ Density } & \multicolumn{3}{|l|}{ Growth habit } \\
\hline Scale & Piece & $\%$ & Scale & Piece & $\%$ & Scale & Piece & $\%$ & Scale & Piece & $\%$ \\
\hline 1 & 0 & 0.00 & 1 & 0 & 0.0 & 1 & 3 & 0.53 & 1 & 17 & 2.99 \\
\hline 3 & 151 & 26.58 & 3 & 98 & 17.3 & 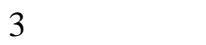 & 165 & 29.05 & 3 & 232 & 40.85 \\
\hline 5 & 405 & 71.30 & 5 & 426 & 75.0 & 5 & 387 & 68.13 & 5 & 299 & 52.64 \\
\hline 7 & 12 & 2.11 & 7 & 44 & 7.7 & 7 & 13 & 2.29 & 7 & 19 & 3.35 \\
\hline 9 & 0 & 0.00 & 9 & 0 & 0.0 & 9 & 0 & 0.00 & 9 & 1 & 0.18 \\
\hline Lowest & 2.25 & & Lowest & 2.75 & & Lowest & 1.25 & & Lowest & 1.00 & \\
\hline Highest & 6.50 & & Highest & 7.75 & & Highest & 6.88 & & Highest & 8.00 & \\
\hline Average & 4.37 & & Average & 4.66 & & Average & 4.22 & & Average & 4.03 & \\
\hline sd & 0.78 & & sd & 0.82 & & $\mathrm{Sd}$ & 0.828 & & sd & 1.066 & \\
\hline \multicolumn{3}{|c|}{ Tendency to inflorescences } & \multicolumn{3}{|c|}{$\begin{array}{l}\text { Time of inflorescence } \\
\text { emergence }\end{array}$} & \multicolumn{3}{|l|}{ Plant height } & \multicolumn{3}{|c|}{$\begin{array}{l}\text { Length of the upper } \\
\text { internode }\end{array}$} \\
\hline Scale & Piece & $\%$ & Scale & Piece & $\%$ & Limit values & Piece & $\%$ & Limit values & Piece & $\%$ \\
\hline 1 & 10 & 1.76 & 1 & 23 & 4.05 & $<25.09$ & 13 & 2.3 & $<11.76$ & 24 & 4.23 \\
\hline 3 & 110 & 19.37 & 3 & 320 & 56.34 & $25.09-30.82$ & 135 & 23.8 & $11.76-15.20$ & 152 & 26.76 \\
\hline 5 & 334 & 58.80 & 5 & 215 & 37.85 & $30.83-36.56$ & 306 & 53.9 & $15.21-18.65$ & 295 & 51.94 \\
\hline 7 & 111 & 19.54 & 7 & 10 & 1.76 & $36.57-42.30$ & 98 & 17.3 & $18.66-22.10$ & 82 & 14.44 \\
\hline 9 & 3 & 0.53 & 9 & 0 & 0.00 & $>42.30$ & 16 & 2.8 & $>22.10$ & 15 & 2.64 \\
\hline Low & 1.00 & & Lowest & 1.00 & & & 19.35 & & Low & 8.31 & \\
\hline Highest & 9.00 & & Highest & 7.50 & & Highest & 48.05 & & Highest & 25.54 & \\
\hline Average & 4.72 & & Average & 3.63 & & Average & 33.34 & & Average & 16.45 & \\
\hline sd & 1.244 & & sd & 1.072 & & $\mathrm{Sd}$ & 4.20 & & sd & 2.632 & \\
\hline
\end{tabular}

sd: standard deviation

\section{Color}

The findings indicated that perennial ryegrass genotypes colors were found the lowest for 2.75 (light green), the highest for 7.75 (dark green), 0.820 for standard deviation. Genotypes indicated $17.3 \%$ for light green, $75 \%$ for medium green and $7.7 \%$ for dark green (Table 2). Color of perennial ryegrass genotypes vary according to many factors, although the color of each genotype was shown to be hereditary. Genetic color is called when the turf does not actively grow under stress (Morris, 2005). The color tone of the grass plants to be selected should be investigated and firstly should be dealt (Avcioglu, 1997). More dark green plants were visually and aesthetically preferred in lawn (Beard, 1973; Avcioglu, 1997; Casler and Duncan, 2003; Thorogood, 2003). Variations between genotypes provided the opportunity to select the desired shades of green.

\section{Plant density}

Plant density was the lowest for 1.25 (very low), the highest for 6.88 (high) and 0.828 for standard deviation. Genotypes were $0.53 \%$ for very low, $5.29 \%$ for low, $68.13 \%$ medium and $2.29 \%$ for high in terms of plant density (Table 2). One of the factors affecting aesthetic was density in the lawn areas (Beard, 1973). The visual quality value was linearly related to the density. Representing the number of shoots per unit density (frequency) value was desirable high for quality turf areas. Because, it was important to create a good green area for plants often prevented foreign weed and for completely cover the area (Beart, 1973; Avcioglu, 1997). Out of plant species, green field intensity are affected by factors such as climate, season, soil moisture, form tools, cutting height, format, frequency and nitrogen fertilization, (Beart, 1973; Avcioglu, 1997). 


\section{Growth habit}

Plant growth habit was lowest for scale value 1 (erect), highest for 8 (prostrate) and 1.066 for standard deviation. Ryegrass genotypes showed $2.99 \%$ for erect, \% 40.85 for semi-erect, $52.64 \%$ for medium, $3.35 \%$ for semi-prostrate, $0.18 \%$ for prostrate (Table 2). As is known, perennial ryegrasses are grown forage crops and main lawn areas. The seed production in both purposes is required. Erect development of the plant was important for seed production. Growth habit is influenced by the genotype of plant in addition to the many environmental factors, the nitrogen fertilization, irrigation, sowing, season. Theoretically, the potential for perennial ryegrass seed yield was $7000 \mathrm{~kg} \mathrm{ha}^{-1}$, but $1 / 10$ were utilized in practice (Hebblethwaite et al., 1980). The reasons of tiller with losses bedtime notables poor seed retention and poor grain formation (Burbidge et al., 1978), lying in plants lack of flowering, pollen moved disorder and harvest losses increase in the (Burbidge et al., 1978; Wright and Hebblethwaite, 1979) were known. Researches showed spikelet number increased when lodging prevented (Hebblethwaite et al., 1982). The lodging was not desirable because of adverse effects on seed yield. Therefore perpendicular growth pattern of genotypes in breeding has a different significance.

\section{Tendency to inflorescences}

In the study, tendency to inflorescences were the lowest for1.0 (none or very weak), the highest for 9.0 (very strong) and 1.244 for standard deviation. Tendency to inflorescences of genotypes was $1.76 \%$ for very weak, $\% 19.37$ for weak, \% 58.80 for medium, $19.54 \%$ for strong and $0.53 \%$ for very strong (Table 2). Heading in lawn area was not desirable because it damaged lawn quality. Although trend of heading in lawn areas were not desirable because it damage quality of lawn, there was no such problem for areas that was cultivated for forage. Tendency of heading was desirable for seed production. Tendency to heading are affected by fertilizing, day length, vernalization, temperature, irrigation status, upbringing purpose. In addition to these factors, the genetic structure was very important. Research results showed non-heading, very weak or very strong tendency to inflorescences of genotypes.

\section{Time of heading}

In the study, time of heading was lowest for 1.0 (very early), the highest for 7.5 (late), and 1.072 for standard deviation. Heading time of genotypes was $4.05 \%$ for very early, $56.34 \%$ for early, $37.85 \%$ for intermediate and $1.76 \%$ for late (Table 2). The control of the entering of the green fields grasses in generative period means control of the quality of lawn (Avcioglu, 1997). Because the grass plants that enter stem elongation and heading stages change their appearance, desired visual uniformity was damaged (Avcioglu, 1997). In the synthetic varieties breeding, commonly used in perennial ryegrass breeding, must have to be in the same heading time of clones. If the clones tested are simultaneously flowered, they give good results. For many species, early blooming clones and late blooming clones must be the differences between 3-4 days (Tosun, 1973). In the study, significant differences between time of heading of the perennial ryegrass genotypes were important for the prospective breeding programs.

\section{Plant height}

Plant height in perennial ryegrass genotypes was the lowest for $19.35 \mathrm{~cm}$, the highest for $48.05 \mathrm{~cm}$ and 4.20 for standard deviation. Plant height values of 568 perennial ryegrass genotypes were found $2.3 \%$ for very short $(<25.9$ $\mathrm{cm}), 23.8 \%$ for short $(25.09$ to $30.82 \mathrm{~cm}), 53.9 \%$ for medium (30.83 to $36.56 \mathrm{~cm}), 17.3 \%$ for tall $(36.57$ to $42.30 \mathrm{~cm}$ ) and $2.8 \%$ for very tall $(>42.30 \mathrm{~cm}$ ) (Table 2). For perennial ryegrass, due to close relationship between elements of yield and plant height, the high stature plats were desirable if they were cultivated as forage corps. The perennial ryegrass that would be used in green area was not desired high stature plant, because being green herbage yield was high, rapid growth, both aesthetically as well as more maintenance (watering, mowing, fertilization etc.) would require. Perennial ryegrass no matter what purpose it was cultivated, the seed production was needed. Short plant height was not desirable also because of it was not appropriate for mechanized harvesting. The high difference between average plant heights will increase our chances of catching the plants desirable.

\section{Upper internode length}

The upper internode length was lowest for $8.31 \mathrm{~cm}$, the highest for $25.54 \mathrm{~cm}$ and 2.632 for standard deviation. Perennial ryegrass genotypes were $4.23 \%$ for very short $(<11.76 \mathrm{~cm}), 26.76 \%$ for short $(11.76$ to $15.20 \mathrm{~cm})$, $51.94 \%$ for medium ( 15.21 to $18.65 \mathrm{~cm}), 14.44 \%$ for long $(18.66$ to $22.10 \mathrm{~cm}), 2.64 \%$ for very long $(>22.10 \mathrm{~cm})$ (Table 2). The longest internode distance was the upper internode distance and this play important role for determination of plant height. Okkaoglu (2006) found closed and positive relationship between the length of the internode and the plant height.

\section{Spike length}

Spike length showed lowest for $6.76 \mathrm{~cm}$, the highest for $16.28 \mathrm{~cm}$, and 2.632 for standard deviation (Table 3). Perennial ryegrass genotypes were $11.5 \%$ for very short $(<8.67 \mathrm{~cm}), 32.39 \%$ for short $(8.67$ to $10.57 \mathrm{~cm}), 47.01 \%$ for medium (10.58 to $12.48 \mathrm{~cm}), 14.08 \%$ for long (12.49 to $13.39 \mathrm{~cm}$ ) and $1.41 \%$ for very long $(>14.39 \mathrm{~cm})$ (Table $3)$. Genotype, agricultural practices and the environment influence spike length. For increase seed yield, it should be dealt with the characteristics related to seed yield. Acar at al. (2010) reported that spike height were important feature for seed yield. Spike length was important to determine the level of the development of generative organs and it could be said that seed yield was also high for the much more spikelet at grasses with long spike (Okkaoglu, 2006). Taking into consideration other characteristics, the long spike could be selected for seed yield. 
Table 3. Statistical parameters and frequency distribution of spike length, leaf length, leaf width, leaf area, leaf shape, the number of spikelets per spike, seed yield per spike, thousand grain weight, in 568 perennial ryegrass genotypes

\begin{tabular}{|c|c|c|c|c|c|c|c|c|c|c|c|}
\hline \multicolumn{3}{|l|}{ Spike length } & \multicolumn{3}{|l|}{ Leaf length } & \multicolumn{3}{|l|}{ Leaf width } & \multicolumn{3}{|l|}{ Leaf area } \\
\hline Limit values & Piec & $\%$ & Limit values & Piece & $\%$ & Limit values & Piece & $\%$ & Limit value & Piece & $\%$ \\
\hline $\begin{array}{l}<8.67 \\
\end{array}$ & 29 & 5.11 & $6.44-8.06$ & 59 & 10.39 & $<2.73$ & 23 & 4.05 & $<2.31$ & 36 & 6.34 \\
\hline $8.67-10.57$ & 184 & 32.39 & $8.07-9.69$ & 326 & 57.39 & $2.73-3.04$ & 206 & 36.27 & $2.31-2.94$ & 259 & 45.60 \\
\hline $10.58-12.48$ & 267 & 47.01 & $9.70-11.32$ & 171 & 30.11 & $3.05-3.36$ & 262 & 46.13 & $2.95-3.58$ & 235 & 41.37 \\
\hline $12.49-14.39$ & 80 & 14.08 & $11.33-12.95$ & 8 & 1.41 & $3.37-3.68$ & 73 & 12.85 & $3.59-4.22$ & 32 & 5.63 \\
\hline$>14.39$ & 8 & 1.41 & $12.96-14.58$ & 4 & 0.70 & $>3.68$ & 4 & 0.70 & $>4.22$ & 6 & 1.06 \\
\hline Lowest & 6.76 & & Lowest & 6.44 & & Lowest & 2.41 & & Lowest & 1.68 & \\
\hline Highest & 16.2 & & Highest & 14.57 & & Highest & 4.01 & & Highest & 4.87 & \\
\hline Average & 11.0 & & Average & 9.32 & & Average & 3.12 & & Average & 2.94 & \\
\hline sd & 2.63 & & sd & 1.027 & & sd & 0.235 & & sd & 0.445 & \\
\hline
\end{tabular}

\begin{tabular}{|c|c|c|c|c|c|c|c|c|c|c|}
\hline \multicolumn{2}{|l|}{ Leaf shape } & \multicolumn{3}{|c|}{$\begin{array}{l}\text { The number of spikelets } \\
\text { per spike }\end{array}$} & \multicolumn{3}{|c|}{ Seed yield per spike } & \multicolumn{3}{|c|}{ Thousand grain weight } \\
\hline Limit values & Piece $\%$ & Limit values & Piece & $\%$ & Limit values & Piece & $\%$ & Limit value & Piece & $\%$ \\
\hline$<26.08$ & 9.86 & $<14.06$ & 10 & 1.76 & $<0.055$ & 53 & 9.33 & $<1.46$ & 12 & 2.11 \\
\hline $26.08-30.93$ & $283 \quad 49.82$ & $14.06-16.48$ & 105 & 18.49 & $0.055-0.078$ & 248 & 43.66 & $1.46-1.68$ & 116 & 20.42 \\
\hline $30.94-35.79$ & $190 \quad 33.45$ & $16.49-18.91$ & 334 & 58.80 & $0.079-0.102$ & 210 & 36.97 & $1.69-1.91$ & 248 & 43.66 \\
\hline $35.80-40.65$ & 5.99 & $18.92-21.34$ & 109 & 19.19 & $0.103-0.126$ & 50 & 8.80 & $1.92-2.14$ & 157 & 27.64 \\
\hline$>40.65$ & 0.88 & $>21.34$ & 10 & 1.76 & $>0.126$ & 7 & 1.23 & $>2.14$ & 35 & 6.16 \\
\hline Lowest & 21.23 & Lowest & 11.63 & & Lowest & 0.031 & & Lowest & 1.23 & \\
\hline Highest & 45.52 & Highest & 23.75 & & Highest & 0.151 & & Highest & 2.38 & \\
\hline Average & 30.41 & Average & 17.65 & & Average & 0.079 & & Average & 1.84 & \\
\hline sd & 3.508 & sd & 1.635 & & sd & 0.019 & & sd & 0.193 & \\
\hline
\end{tabular}

sd: standard deviation

\section{Leaf length}

The leaf length was lowest for $6.44 \mathrm{~cm}$, the highest for $14.57 \mathrm{~cm}$ and 1.027 for standard deviation. Leaf length of 568 genotypes was $10.39 \%$ for very short $(<8.07 \mathrm{~cm})$, $57.39 \%$ for short $(8.07-9.69), 30.11 \%$ for medium $(9.70-$ $11.32 \mathrm{~cm}), 1.41 \%$ for long $(11.33-12.95 \mathrm{~cm}), 0.70 \%$ for very long (>12.95 cm) (Table 3). Many factors such as climate, agricultural practices and genotype affect leaf length. According to Beard (1973), the cells length primarily influences leaf length, the number of cells have less impact on leaf length, long days increases also leaf length, low intensity of the light increases also leaf length, normal temperature influence positively leaf length, but extreme temperatures influence negatively leaf length, scarcity of water decreases the total area and size of the leaf (Hazard and Ghesquiere, 1997). While the longleaved plants were more yields in sparse mowing, the short-leaved plants were more yield in dense mowing. According to researchers, while short-leaved plants were desired at heavy grazing conditions, the long-leaved plants were desired for vice versa condition.

\section{Leaf width}

Leaf width was the lowest for $2.41 \mathrm{~mm}$, the highest for $4.01 \mathrm{~mm}$ and 0.235 for standard deviation. Perennial ryegrass genotypes was $4.05 \%$ for very narrow $(<2.93$ $\mathrm{mm}), 36.27 \%$ for narrow (2.73 to $3.04 \mathrm{~mm}$ ), $46.13 \%$ for medium (3.05 to $3.36 \mathrm{~mm}$ ), $12.85 \%$ for broad (3.37 to $3.68 \mathrm{~mm}$ ) and $0.70 \%$ for very broad (> $3.68 \mathrm{~mm}$ ) (Table $3)$. The environment conditions, cultural practices and many factors influence leaf width. The main constituent of the green texture of turfgrass is width of the leaf blade (Avcioglu, 1997). Leaves width are classified as a very thin $(<1 \mathrm{~mm})$, thin (1 to $2 \mathrm{~mm})$, medium ( 2 to $3 \mathrm{~mm}$ ), rude (3 to $4 \mathrm{~mm}$ ) and very rude $(>4 \mathrm{~mm}$ ) (Beard, 1973; Avcioglu, 1997). Perennial ryegrass plants constitute the medium tissue. Leaf width is desired as thin as possible for turf types, while leaf with is desired to be large for forage type. Therefore, the differences between the averages of the leaf length provide the convenience of selecting desired plants.

\section{Leaf area}

Leaf area was lowest for $1.68 \mathrm{~cm}^{2}$, the highest for 4.87 $\mathrm{cm}^{2}$ and 0.445 for standard deviation. Perennial ryegrass genotypes were $6.34 \%$ for very small $(<2.31 \mathrm{~cm} 2)$, $45.60 \%$ for small (2.31 to $2.94 \mathrm{~cm}^{2}$ ) $41.37 \%$ for medium ( 2.95 to $\left.3.58 \mathrm{~cm}^{2}\right), 5.63 \%$ for large $\left(3.59\right.$ to $\left.4.22 \mathrm{~cm}^{2}\right)$ and $1.06 \%$ for very large $\left(>4.22 \mathrm{~cm}^{2}\right)$ (Table 3$)$. Leaf area has two components as leaf length and leaf width. Therefore, leaf area was influenced also depending on these factors. While leaf area increases, photosynthesis area increases also; and therefore, photosynthetic products would increase yield also. The increase in leaf area will positively influence both grass quality and grass yield. Therefore, genotypes that have great leaf area are appropriate in selection for forage crops. The plants that would be used in turfgrass plant were different. Finetextured, tiny leave was desired in turfgrass. Large leaf area, producing rapid growth, frequent mowing was not 
desirable also in turfgrass. For these reasons the turfgrass was not large leaf areas desirable. For these reasons large leaf area in green space is inconvenient.

\section{Leaf shape}

Leaf length / width ratio (leaf shape) was lowest for 21.23, highest for 45.52 and 3.508 for standard deviation. Leaf length / width ratio values of 568 perennial ryegrass genotypes was found $9.86 \%$ for very low $(<8.26), 49.82 \%$ for low (26.08 to 30.93 ), $33.45 \%$ for medium (30.94 to $35.79), 5.99 \%$ for high (35.80 to $40.65 \%$ ) and $0.88 \%$ for very high (> 40.65) (Table 3). Leaf length / width ratio varies depending on the leaf length and width. High leaf length/width ratio of the plants that would be used at green fields means long and thin leaves. Therefore, leaves of the green areas appear more often and stem less appear and fine texture of the leaves will provide better turf quality.

\section{Number of spikelets per spike}

Spikelet number was the lowest for 11.63, the highest for 23.75 and 1.635 for standard deviation. Spikelet number values of 568 perennial ryegrass genotypes were $1.76 \%$ for very few $(<6.14), 18.49 \%$ for few $(14.06$ to $16.48), 58.80 \%$ for medium (16.49 to 18.91$), 19.19 \%$ for many (18.92 to 21.34 ) and $1.76 \%$ for very many (> 21.34) (Table 3).The reproduction and trade of cultivated plants can be done most easily via seed. Therefore, when developing varieties in perennial ryegrass plants, seed yield needs to be high for the purposes both lawn and forage crops. The number of spikelets per spike is affected by genotypes rather than environmental factors. Okkaoglu (2006) reported that the number of the spikelets per spike has positive and very high effect on seed yield. Consequently, a high number of spikelets were good selection criteria for seed yield (Okkaoglu, 2006). With the aim of developing high yielding varieties of seeds, the genotypes that have many spikelets could be used.

\section{Seed yield}

Seed yield was the lowest for $0.031 \mathrm{~g}$, the highest for $0.151 \mathrm{~g}$ and 0.193 for standard deviation. Seed yield of 568 perennial ryegrass genotypes was $9.33 \%$ for very few $(<0.055), 43.66 \%$ for few $(0.055$ to 0.078$), 39.97 \%$ for medium $(0.079$ to 0.102$), 8.80 \%$ for many $(0.103$ to $0.126)$ and $1.23 \%$ for very many (>0.126) (Table 3 ). Seed yield per spike depends on number of spikelets per spike, number of flowers in spikelet, fertile flower number and thousand-grain weight. Some of these were controlled by genetic structure; the other part was formed by the effect of the environmental factors. The significant differences were determined among genotypes in terms of seed yield per spike in this study. Genotypes with high seed yield per spike if the other characteristics were good also could be directly selected; or using breeding methods in the form of this property to be transferred to other plants.

\section{Thousand-grain weight}

Thousand-grain weight was the lowest for $1.23 \mathrm{~g}$, the highest for $2.38 \mathrm{~g}$ and 0.193 for standard deviation.
Thousand grain weight values of 568 perennial ryegrass genotypes were $2.11 \%$ for very few $(<1.46 \mathrm{~g}), 20.42 \%$ for few (1.46 to $1.68 \mathrm{~g}$ ), $43.66 \%$ for medium (1.69 to $1.91 \mathrm{~g}$ ), $27.64 \%$ for many (1.92 to $2.14 \mathrm{~g} \%$ ) and $6.16 \%$ for very many (> $2.14 \mathrm{~g}$ ) (Table 3). Thousand-grain weight shows that the seed contains enough endosperm and has healthy embryo, and this is important also in terms of seed standards in laboratory (Okkaoglu, 2006). Large seeds that have high thousand grain weight have high endosperm proportionally and so, large seeds were desirable always because of rapid and powerful seedling production (Soya et al., 2005).

Research results showed that there were significant differences between genotypes of perennial ryegrass in terms of investigated all traits. Significant variations among the perennial ryegrass genotypes showed that Ankara is the one of the important gene center for perennial ryegrass. Great changes potential of the characteristics observed increase the chance of selection of the plants that were desirable. In conclusion, genotypes of the perennial ryegrass that would be used breeding efforts were determined. As a result of all the observations and measurements, 13 genotypes for forage crops, 10 genotypes for turfgrass and 14 genotypes for high seed yield were selected for using in future breeding programs

\section{ACKNOWLEDGMENTS}

This work was taken a part from Ph.D. thesis of Abdullah Ozkose.

\section{LITERATURE CITED}

Acar Z., I. Ayan, O. Tongel, H. Mut and U. Basaran. 2010. Morphological traits of perennial ryegrass accessions in Black Sea Region of Turkey. The Contributions of Grasslands to Conservation of Mediterranean Biodiversity. pp. 117-120, Alicante-Spain.

Acikgoz, E. 1994. Technique of construction and maintenance of Grasslands, Bursa: Cevre Ltd. Co. Publications. No: 4. (In Turkish)

Anonymous. 1990. International Union For The Protection Of New Varieties Of Plants (UPOV), Guidelines for The Conduct of Test For Distinctness, Homogeneity any Stability, Ryegrass (Lolium spp.). http://www.upov.org/en/publications/tgrom/tg004/tg_4_7.pdf. (Accessed September 2005)

Anonymous, 1998. Ryegrass (Lolium spp.), Guidelines for the conduct of tests for distinctness, homogeneity and stability. Republic of Turkey Ministry of Food, Agriculture and Livestock, Variety Registration and Seed Certification Centre, Ankara, Turkey (In Turkish)

Anonymous. 2005. United States Department of Agriculture (USDA), Agricultural Research Service, National Plant Germplasm System, National Turfgrass Evaluation Program (NTEP) (USA). http://www.arsgrin.gov/npgs/descriptors/grass (Accessed December2005)

Avcioglu, R. 1997. Turf Technique (Turf Establishment \&Management), Ege University Press. Izmir. (In Turkish)

Beard, J.B. 1973. Turfgrass: Science and Culture, Prentice-Hall, International, Inc.USA.

Bolaric, S., S. Bart, A.E. Melchinger and U.K. Posselt. 2005. Molecular genetic diversity within and among German ecotypes in comparison to European Perennial ryegrass cultivars. Plant Breeding. 124:257-267. 
Burbidge, A., P.D. Hebblethwaite and J.D. Ivins. 1978. Lodging studies in Lolium perenne grown for seed. J. Agr. Sci. Camb. 90:269-274

Casler M.D. and R.R. Duncan. 2003. Turfgrass Biology, Genetics and Breeding, Jhon Wiley and Sons, Inc. USA.

Hazard, L. and M. Ghesquiere. 1997. Productivity under contrasting cutting regimes of perennial ryegrass selected for short and long leaves. Euphytica. 95:295-299.

Hebblethwaite, P.D., D. Wright and A. Noble. 1980. Some physiological aspect of seed yield in Lolium perenne. In: Seed production, ed. Hebblethwaite P.D., 71-90 Butterworths, London.

Hebblethwaite, P.D., J.G. Hampton and J.S. Mc Laren. 1982. The chemical control of growth, development and yield of Lolium perenne grown for seed. In: Chemical Manipulation of Crop Growth and Development, ed. Mc Laren J.S., 505523. Butterworths. London,

Hoover, M.M., M.A. Hein, W.A. Dayton and C.O. Erlanson. 1948. Grass, The Yearbook of Agriculture, United States Department of Agriculture. The Superintendent of Document, Washington, 25, D.D., USA.

Kir, B., R. Avcioglu, G. Demiroglu and A. Simic. 2010. Performances of some cool season turfgrass species in Mediterranean environment: I. Lolium perenne L., Festuca arundinacea Schreb., Poa pratensis L., and Agrostis tenuis Sibth. Turk. J. Field Crops, 15(2):174-179

Mill. R.R. 1985. Lolium L. In: Flora of Turkey and the East Aegeen Island, ed. Davis, P.H. Vol 9:445-451, Edinburg: Edinburg University Press, UK.
Morris, K.N. 2005. A Guide to NTEP (National Turfgrass Evaluation Program) Turfgrass Ratings. http://www.ntep.org/reports/ratings.htm\#introduction (Accessed November 2005)

Okkaoglu, H. 2006. Investigations on the seed yield and various agronomical characteristics of some forage grasses MSc. Thesis. In Field Crops Department, Institute of Natural and Applied Sciences, Ege University, Izmir, Turkey, p.106.

Soya, H., R. Avcioglu, H. Geren, B. Kir, G. Demiroglu and Y.T. Kavut. 2005. Investigations on the physical characteristics of some forage crops and turfgrass seeds used in Turkey. Turkey 2. Seed Congress, pp. $242-247$ Adana.

Surmen, M., T. Yavuz, S. Albayrak, N. Cankaya. 2013. Forage yield and quality of perennial ryegrass (Lolium perenne $\mathrm{L}$.) lines in the Black Sea Coastal Area of Turkey. Turk. J. Field Crops 18(1):40-45

Thorogood, D. 2003. Perennial ryegrass (Lolium perenne L.). In: Turfgrass Biology, Genetics and Breeding, ed. Casler, M.D. and Duncan, R. R., 75-100, John Wiley and Sons, Inc, USA.

Tosun, F. 1973. Breeding Perennial Forage Grasses, Erzurum: Ataturk University Press No: 211.

Watson, L. and M.J. Dallwitz. 1994. The Grass Genera of The World. 2. Edition. CAB International, Wallingford Oxon OX10 8DE.

Wright, D. and P.D. Hebblethwaite. 1979. Lodging studies in Lolium perenne grown for seed: 3. Chemical control of lodging. J. of Agric. Sci. 93:669-679. 